\title{
LINKS OR DISCONNECT: A FIRST CONSIDERATION OF INFLATION EXPECTATIONS AND INFLATION CREDIBILITY, WITH SPECIFIC reference to South Africa
}

\author{
Jannie Rossouw \\ SA Reserve Bank ${ }^{1}$ and Department of Economics, University of Pretoria \\ Vishnu Padayachee \\ School of Development Studies, University of KwaZulu-Natal \\ Adél Bosch \\ SA Reserve Bank
}

\begin{abstract}
This paper compares international and domestic inflation expectations and inflation credibility, and hypothesises about a possible link or disconnect between inflation expectations and inflation credibility among South Africans. No similar tests have previously been performed using South African data, and there is also a general lack of domestic and international literature on any such possible link or disconnect. While research shows that inflation expectations are taken into account by all countries targeting inflation, inflation credibility is very seldom considered. Although the hypothesis is confirmed in certain instances, it is refuted by a disconnect between the inflation expectations and inflation credibility of male and female respondents in South Africa, which cannot be explained by available data.
\end{abstract}

Keywords: Estimation; inflation; inflation credibility; inflation expectations; literature on inflation expectations; monetary policy; multinomial analysis; surveys

JEL E31, 52, 58

1

\section{Introduction}

This paper considers inflation expectations (a focus on future inflation) and inflation credibility (a focus on historical inflation). By means of a multinomial model, it tests whether there is a link or a disconnect between inflation expectations and inflation credibility among South Africans. This is the first comparison of this nature using South African data. The analysis and argument are developed as follows: Section 2 commences with a comparative literature review of inflation expectations and inflation credibility in inflationtargeting countries. Section 3 considers inflation expectations in these countries, and Section 4 considers inflation credibility in inflationtargeting countries. Section 5 considers the survey of inflation expectations among South African households in the fourth quarter of 2006. ${ }^{2}$ Section 6 highlights a survey of inflation credibility among South African households in the same quarter of 2006. The survey results and multinomial estimation results are compared in Section 7, and conclusions follow in Section 8.

\section{2}

Comparative literature review of inflation expectations and inflation credibility in inflationtargeting countries

Based on a definition by the International Monetary Fund (IMF) (2005: 161, 162), ${ }^{3}$ Allen et al. (2006: 5) identified 23 inflation-targeting 
countries in 2006. Vega and Winkelried (2005: $165)$ identified the same group of 23 countries as inflation targeters. The group excludes "indirect" inflation targeters like the Common Monetary Area partner countries of South Africa (Lesotho, Namibia and Swaziland) which follow a policy of pegging the exchange rates of their currencies to the exchange rate of a country targeting inflation. Although it could be argued that such "indirect targeters" should be included, no support for such an approach can be found in literature.

This paper includes Ghana as the $24^{\text {th }}$ member of a cluster of inflation-targeting countries, ${ }^{4}$ as it has complied with the IMF's definition since May 2007 (Addison, 2008: 1; Amoah \& Mumuni, 2008: 16). Between 2002 and 2007, Ghana practised inflation targeting lite (Carare \& Stone, 2003), as it combined an inflation target and a money supply target to anchor its monetary policy stance. ${ }^{5}$

Fracasso et al. (2003) and the Bank of Iceland $(2003)^{6}$ considered various aspects of the monetary policy reports (known, for instance, as Inflation Reports, Monetary Bulletins or Monetary Policy Reviews) of the central banks of 21 countries identified at the time as inflation targeters, and assessed the reports of 20 of these central banks. ${ }^{\text {. }}$ The main aim of the assessment was to rate the overall quality of these reports relative to one another (Fracasso et al., 2003: 1, 24, 25) and to consider a broad variety of disclosure aspects such as the clarity of assumptions, inflation forecasts, the monetary policy decision-making process and the quality of information. The assessment did not include an analysis of the reporting of inflation expectation or inflation credibility surveys. Likewise, a comparison by Leeper (2003) of the monetary policy reports of the Bank of England, the Reserve Bank of New Zealand and the Swedish Riksbank makes no reference to inflation expectations or inflation credibility.

Blinder et al. (2008) assess the degree to which inflation targets anchor the public's long-run inflation expectations, but make no reference to inflation credibility surveys. Other literature dealing with matters relating to or supporting inflation targeting, such as the communication strategies of central banks (Bank for International Settlements, 2008; Blinder \&
Wyplosz, 2005; Ehrmann \& Fratzscher, 2005), omits any reference to inflation expectation or inflation credibility surveys.

\section{3}

\section{Inflation expectations}

This section reviews the scope and coverage of inflation expectations in the monetary policy reports by central banks in inflation-targeting countries, a notable gap in the existing literature. Inflation expectations reported in the periodic monetary policy reports of the cluster of 24 countries regarded as inflation targeters are presented in Table A1 in Appendix A and Table B1 in Appendix B.

In summary, the central bank of one country (Slovakia) considers only a measurement of interest rates on different classes of traded financial assets as an indicator of inflation expectations. Central banks in eight other countries (Canada, Chile, Colombia, Iceland, Israel, Mexico, Sweden and Thailand) consider both rates on traded financial assets and surveys of inflation expectations from groups of respondents, although the scope and description of such groups differ considerably from country to country. Central banks in 13 countries (Australia, Brazil, the Czech Republic, Ghana, Hungary, Indonesia, New Zealand, Norway, Peru, the Philippines, Poland, Romania and South Korea) consider only surveys of inflation expectations, again from groups of respondents that differ considerably between these countries. The central bank of one country (South Africa) considers surveys of inflation expectations and inflation forecasts reported as inflation expectations. Lastly, in the case of one country (the United Kingdom) the central bank considers rates on traded financial assets, surveys of inflation expectations and inflation forecasts reported as inflation expectations. Central banks use either own surveys (seven cases), surveys by other institutions (six instances) or a combination of these two approaches (11 central banks) to obtain information on inflation expectations.

The primary aim of periodic inflation expectation surveys is to assess whether expectations remain anchored in the current (historical) 
rate of inflation (Sveriges Riksbank [S.a.]; see also Palmqvist \& Stromberg, 2004). In respect of South Africa, Van Heerden and Styger (2009) used an ARFIMA model to show a close relationship between expected inflation, based on historical inflation, and the realised rate of actual inflation. Surveys therefore serve as an early warning of any possible deanchoring (sometimes called unanchoring) of expectations, owing, for example, to an unwarranted relaxation of monetary policies in the face of rising inflation (Banco Central de Chile, 2008: 13; Portugal, 2008; Viñals, 2007: 2). The SA Reserve Bank also warned that expectations of price increases not addressed by appropriate monetary policy could result in the danger that " ... inflation expectations will become less anchored ..." (Mboweni, 2008: 1) in the current rate of inflation.

Forsells and Kenny (2002: 25) maintain that "(s)urveys are useful because they provide independent ... measures of inflation expectations, a key variable that a central bank can use in its design of an optimal monetary policy geared toward the achievement of price stability". Central banks use the findings of inflation expectation surveys to evaluate the credibility of their inflation-fighting policies (Kershoff et al., 1999: 6), because credibility is helpful in reducing the output loss that often accompanies disinflationary monetary policies (Kahn \& Parish, 1998: 7). The extensive use of inflation expectations by countries targeting inflation therefore comes as no surprise.

\section{Inflation credibility surveys}

Questions and doubts as to the accuracy of inflation figures can naturally feed into inflation credibility problems (Rossouw \& Padayachee, 2009: 315). In the South African context, errors impacting on the accuracy of inflation figures are reported from time to time. One example is 1991, when incorrect price increases were reported owing to a mistake in the calculation of the producer price index (Rossouw, 2008: 88). Similarly, it was announced on 31 May 2003 that an error had been made in the calculation of the residential rent component of the consumer price index (CPI), which resulted in the over-measurement of inflation (Rossouw, 2008: 86). In 2008, Investec (2008) argued that a delay in the introduction of South Africa's rebased CPI had caused an over-measurement of 2,2 percentage points in the domestic rate of inflation. Such errors and delays not only erode the accuracy of inflation figures, but can also result in an inappropriate monetary policy stance in an inflation-targeting regime.

Likewise, amendments to the specification of the rate of inflation used for targeting purposes can erode inflation credibility, particularly when the target (either a point or a range) is increased (see Du Plessis, 2003: 407-409; Du Plessis, 2005: 94, 95 on the periodic re-specification of the South African inflation target).

Döhring and Mordon (2007: 1) and Issing (2006: 211-213) describe inflation credibility problems in the Euro Area since January 2002. Consumer perceptions are that prices have increased considerably above the official rate of inflation since the introduction of the Euro and will continue to do so. Although their analysis is outside the scope of this paper, as the ECB is not an inflation-targeter, it reconfirms that inflation credibility can be eroded by public perceptions and that a lack of credibility can feed into inflation expectations.

A review of the literature shows that perceptions of the general acceptance and credibility of historical inflation figures are surveyed officially among inflation-targeting countries only in New Zealand and Sweden (Jonung, 1981; Palmqvist \& Stromberg, 2004; Reserve Bank of New Zealand, [S.a.]a; Rossouw \& Padayachee, 2009). A representative inflation credibility survey was completed only once before in South Africa (Rossouw, 2008).

Inflation perceptions by the general public have been surveyed by the Reserve Bank of New Zealand on a quarterly basis by means of its J5 Marketscope Survey - Expectations of inflation survey since 1985 (Reserve Bank of New Zealand, [S.a.]a). These surveys measure prevailing perceptions of the accuracy of the current rate of inflation in New Zealand. The survey results are not published in the Monetary Policy Statement of the Reserve Bank of New Zealand. 
Inflation perceptions on the part of Swedish companies are surveyed by the Swedish Riksbank prior to the publication of each Monetary Policy Report (Sveriges Riksbank, 2008: 57). It would appear that from 2007 the survey results have been published in the Report. In addition, Statistics Sweden has surveyed the inflation perceptions by Swedish households from 1978, but from 2002 such surveys have been undertaken by Growth from Knowledge, a market-research company (Palmqvist \& Stromberg, 2004). Respondents are requested to indicate whether they perceive prices to be the same, higher or lower than in the year before, and to provide a numerical estimate of their perceived inflation. The surveys of household perceptions are not published in the Monetary Policy Report of the Swedish Riksbank. Of particular importance for this paper is the Swedish finding that perceptions of historical inflation are higher among female respondents than among male respondents, owing to differences in their spending patterns (Brachinger, 2005: 1; Jonung, 1981: 968).

The international experience of differences in the credibility of inflation figures between male and female respondents was also confirmed by the South African survey on inflation credibility (Rossouw, 2008). This survey is considered in Section 6 of this paper.

\section{5}

\section{South African surveys of inflation expectations ${ }^{8}$}

The Bureau for Economic Research (BER) surveys inflation expectations on the part of business executives, financial analysts, households and trade unionists on behalf of the SA Reserve Bank (Kershoff, 2000). As surveys of inflation credibility reported in the next section of this paper focused only on households, this section reports only household inflation expectations in the fourth quarter of $2006 .{ }^{9}$ These surveys were undertaken by AC Nielsen on behalf of the BER as part of a broader research survey. ${ }^{10}$ This approach has been adopted by the BER, as other alternatives would not have guaranteed representative results. Owing to the high rate of illiteracy, postal surveys cannot be used, while telephone surveys reach only a small portion of the population in view of the unequal distribution of fixed-line telephones. These limitations are discussed in a report by the National Gambling Board (2005).

For survey purposes, AC Nielsen conducted personal interviews with 2465 individuals, covering Blacks ${ }^{11}$ and Whites in metropolitan areas, cities, towns and villages throughout South Africa. Asian and Coloured respondents were surveyed only in the major metropolitan areas. The survey results for all respondents and for subsamples for the 4th quarter of 2006 are highlighted in Appendix C. The average responses exclude the responses of respondents who stated that they "don't know" what the rate of inflation would be, as well as the responses of respondents who stated that they expected the rate of inflation to exceed 25 per cent. Of the 2465 respondents, 42 said they expected inflation to be zero per cent. These responses are not included in the survey analysis. In addition to the averages, the responses are also reported according to standard deviation, median, minimum and maximum by the BER, but these latter analyses are not considered in this paper.

To cater for the possibility that individual respondents might not understand the meaning of "inflation", the question posed by AC Nielson takes the form of a statement on price increases over the preceding five years and the preceding year, followed by a question on expected price increases in the current year (see, for instance, Kershoff, 2000). For the quarter under review (the last quarter of 2006), the question/ statement was:

Over the past five years prices increased by on average 5,1 per cent per year. During 2005 prices increased by 3,5 per cent. By how much do you expect prices in general to increase in 2006? (Bureau for Economic Research, 2006: 19)

\section{6}

\section{South African survey of inflation credibility}

Consumers wish to determine the degree to which inflation influences their cost of living over time (see, for instance, Bechtold \& Linz, 
2005; Brachinger, 2005). As the credibility of changes in the CPI as an accurate indication of price increases, and changes in the cost of living have never before been tested in South Africa, six pilot studies ${ }^{12}$ were conducted in preparation for a national survey of inflation credibility. The pilot studies were used to develop the research methodology for a representative survey of inflation credibility in South Africa (see, for instance, Rossouw \& Joubert, 2005; Rossouw $\&$ Padayachee, 2007, for a discussion on the pilot studies).

The survey used for assessing inflation credibility faced challenges similar to those of the BER surveys of households. It was decided to use Markinor (as it was known at the time) to do the fieldwork for the inflation credibility survey, inter alia, to contain cost and to ensure a representative sample of the population (Markinor, [S.a.]; Markinor, 2006). The size of the survey is $3500^{13}$ and it can be split, inter alia, in terms of gender, income and employment status.

The preparatory work for surveying was carried out between August and October 2006, while the survey was completed during October and November 2006. The statement/question put to respondents was:

South Africa's official rate of inflation (CPI) was 5,4 per cent in August 2006. Do you think this is a true reflection of average price increases? (Markinor, 2006)

Insofar as this question makes reference to inflation rather than to price increases, as is the case in the BER survey, its specification is related to the question used in inflation surveys of the Reserve Bank of New Zealand, which states:

Based on your own opinions and what you've seen and heard, what do you think the inflation figure is now? (Reserve Bank of New Zealand, [S.a.]a)

Salient features of the South African survey results for the 4th quarter of 2006 are summarised in Appendix D, while Rossouw (2008) and Rossouw and Padayachee (2009) report the results in detail.

In comparing domestic inflation expectations and inflation credibility surveys to test the hypothesis of a possible link or disconnect between inflation expectations and inflation credibility among South Africans, it is necessary to highlight the difference in the statements/ questions put to respondents in these two surveys. In the first instance, respondents had to consider:

Over the past five years prices increased by on average 5,1 per cent per year. During 2005 prices increased by 3,5 per cent. By how much do you expect prices in general to increase in 2006 ?

It was put to respondents in the second instance that:

South Africa's official rate of inflation (CPI) was 5,4 per cent in August 2006. Do you think this is a true reflection of average price increases?

The first statement/question refers only to prices and price increases, whereas the second statement/question includes both price increases and the rate of inflation.

A number of important matters emerge from this comparison. First, 20,3 per cent of respondents indicated that they did not know what rate of price increases to expect, while 52,9 per cent indicated that they did not know whether the rate of inflation was a true reflection of price increases. It is therefore important to provide for "don't know" as an alternative. This obviates any distortion by other alternatives if the only option for respondents is to take a view on the matter, although the large margin of difference between these responses is somewhat disconcerting. It is not possible to determine whether the difference in questions contributed to differences in the responses recorded.

Secondly, an analysis according to population group shows that Whites recorded the highest reading of respondents who did not accept the historical rate of inflation as accurate. Similarly, Whites also reported the highest level of expected inflation (5,5 per cent). In this case, it seems that low inflation credibility feeds into expectations of future inflation figures.

In terms of age, the analysis shows that respondents over 50 not only had the highest expectation of inflation, but also attached 
the lowest credibility to the historical rate of inflation. This finding also links low inflation credibility and inflation expectations.

The most interesting finding is that relating to gender. As expected, in view of the international experience with the measurement of inflation credibility, male respondents recorded a higher degree of acceptance of historical inflation figures than did female respondents. However, this difference in inflation credibility does not feed into inflation expectations. Both genders reported the expectation that inflation would increase by 5,0 per cent.

\section{7}

\section{Empirical model}

The information from both surveys can be used to determine the likelihood that respondents will choose one outcome over another. Owing to the nature of the options available, a polychotomous choice between three mutually exclusive alternatives provides for the adoption of a multinomial logit model, such as those employed by Mlatsheni and Leibbrandt (2001) and Essop and Yu (2008).

A binary choice model, where the dependent variable can take on the value of one of two choices, can be extended into a framework in which the dependent variable can take on more than two values, that is, a multinomial choice model (Lancaster, 2004). The general multinomial logit model is given by the probability for an individual i to choose the alternative $j$, where $j=1,2,3 \ldots, m$, where $m$ represents the alternatives available. The logistic model can then be defined as:

$P_{i j}=\frac{\exp \left(x_{i} b_{j}\right)}{\sum_{k=0}^{m} \exp \left(x_{i} b_{k}\right)} \quad j=1,2,3, \ldots, m$

Where $P_{i j}$ is the observed outcome and $x_{i}$ and $b_{j}$ represent a vector of parameters associated with the alternative $j$. The multinomial logit model is given by:

$$
P\left(Y_{i}=j X_{i}\right)=\frac{\exp \left(x_{i} b_{j}\right)}{1+\sum_{k=1}^{m} \exp \left(x_{i} b_{k}\right)}
$$

for $j=1,2,3, \ldots, m$
Provision is made for a reference group by normalising the coefficient $b_{0}=0$. The following is the probability of being in the reference group or group 0 :

$$
P\left(Y_{i}=0 \mid X_{i}\right)=\frac{1}{1+\sum_{k=1}^{m} \exp \left(x_{i} b_{k}\right)} \quad \text { for } j=0
$$

The coefficients are estimated by maximum likelihood. The odds or relative risk ratio (RRR) for the multinomial logit are represented by:

$$
\frac{P_{j}}{P_{0}}=\exp \left(x_{i} b_{j}\right)
$$

Where $\exp \left(x_{i} b_{j}\right)$ is the discrete effect of variable $X_{k}$ on the odds. The sign of $\left(x_{i} b_{j}\right)$ gives the sign of the odds effect, but does not depend on the values of $X$. The marginal effect can be derived by taking the first derivative of equation 1 with respect to $x$, holding all other variables constant:

$$
\frac{\partial P_{j}}{\partial x}=P_{j}\left(b_{j}-\sum_{k=1}^{m} P_{k} b_{k}\right)
$$

The marginal effect or partial derivates depend on the value of $x$ and the marginal effect changed as $x$ changes.

\subsection{Model specification}

In this paper both inflation expectations as measured by the BER survey, as well as inflation credibility as measured by the Markinor survey are modelled. First, inflation expectations are modelled. The dependent variable for the model is a categorical variable which represents:

$j=0$ respondents believe inflation to be below 25 per cent, as presented by the BER;

$j=1$ respondents believe inflation to be above 25 per cent, as presented by the BER;

$j=2$ respondents said “don't know”.

The independent variables are based on characteristics that could determine how individuals see inflation. Owing to the nature of this study, there is no information on previous research against which to benchmark the results. The analysis of this empirical model aims to do three things.

The first aim is to determine whether gender plays a role in how respondents experience the 
current inflation rate. Female respondents were coded 1 , male respondents $=0$.

The second aim is to determine whether different population groups experience inflation differently. Whites are represented by 1 , Blacks and Coloureds by 2 and 3 respectively. Asians are coded as 0 .

The third aim is to look at how people at various stages of their lives experience inflation. To measure this, respondents were divided into age groups. The first age group is 16-24, which was coded 1 , followed by $35-39$, which was coded 2 , and the age group $50+$ was coded 3 . The benchmark category $25-34^{14}$ was coded 0 .

In the second survey the same independent variables and benchmark categories were used. The dependent variable, however, measures inflation credibility, for which the categories can be presented as:

$j=0$ respondents believe that the current inflation rate is accurate;

$j=1$ respondents do not believe that the current inflation rate is accurate;

$j=2$ respondents said "don't know".

Both models show a goodness of fit that is significantly different from zero: model one has a $\chi^{2}$ value of 70,26 and model two a $\chi^{2}$ value of 455,12 , indicating that not all estimates are jointly equal to zero. The Pseudo $R^{2}$ value for both models will be between 0 and 1 . For model one, the Pseudo $R^{2}$ is 0,0218 and for model two the $R^{2}$ is 0,0647 . As in binomial logistic models, the Pseudo $R^{2}$ will probably fall between 0 and 0,333 (Pindyck \& Rubinfeld, 1981).

\subsection{Results}

The relative risk ratios (RRR) were analysed at the 90 per cent confidence interval for $H_{0}$ : inflation expectations are the same. At a 10 per cent significance level, the critical $Z$ value will be equal to 1,645 , consequently "not rejecting" the $H_{0}$ if the calculated $Z$ lies between $-1,645$ and $+1,645$.

Table 1 presents the inflation expectations results for the multinomial logit model. Only those values, printed in bold, which represent categories falling outside the critical zone/ acceptance region, will be discussed. First, this analysis attempts to determine what percentage of which population group thinks that the perceived inflation rate is higher than 25 per cent, as opposed to less than 25 per cent. The output from the regression in Table 1 suggests that the odds in this respect are 78,5 per cent (i.e. 100(1-0,214897)) less for Whites than for Asians.

\section{Table 1}

Output from the multinomial regression model for inflation expectations

\begin{tabular}{|c|c|c|c|c|c|c|}
\hline & \multirow[b]{2}{*}{ RRR } & \multirow[b]{2}{*}{ Std. err. } & \multirow[b]{2}{*}{$\mathbf{Z}$} & \multicolumn{3}{|c|}{$\begin{array}{l}\text { Number of obs }=2423 \\
\text { LR chi2 }(14)=70.26 \\
\text { Prob }>\text { chi } 2=0.0000 \\
\text { Pseudo } 22=0.0218 \\
\text { Log likelihood }=-1578.7312\end{array}$} \\
\hline & & & & $P>Z$ & {$[95 \%$ Co } & interval] \\
\hline \multicolumn{7}{|l|}{$\begin{array}{l}1 \text { Average expected } \\
\text { inflation rate above } 25 \\
\text { per cent }\end{array}$} \\
\hline Female & 0.836380 & 0.161130 & -0.93 & 0.354 & 0.573349 & 1.22008 \\
\hline Black & 1.005981 & 0.291626 & 0.02 & 0.984 & 0.569945 & 1.775606 \\
\hline Coloured & 0.767316 & 0.291640 & -0.70 & 0.486 & 0.364294 & 1.616206 \\
\hline White & 0.214897 & 0.086353 & -3.83 & 0.000 & 0.097766 & 0.472358 \\
\hline
\end{tabular}




\begin{tabular}{|l|l|l|l|l|l|l|}
\hline $16-24$ & 0.970370 & 0.247802 & -0.12 & 0.906 & 0.588257 & 1.600692 \\
\hline $35-49$ & 0.933477 & 0.263961 & -0.24 & 0.808 & 0.536300 & 1.624798 \\
\hline $50+$ & 0.988804 & 0.282828 & -0.04 & 0.969 & 0.564470 & 1.732128 \\
\hline 2 Don't know & & & & & & \\
\hline Female & 1.186669 & 0.127132 & 1.60 & 0.110 & 0.961917 & 1.463935 \\
\hline Black & 1.209417 & 0.218309 & 1.05 & 0.292 & 0.849040 & 1.722757 \\
\hline Coloured & 1.082861 & 0.240155 & 0.36 & 0.720 & 0.701123 & 1.672441 \\
\hline White & 0.576164 & 0.115503 & -2.75 & 0.006 & 0.388961 & 0.853466 \\
\hline $16-24$ & 1.200583 & 0.190837 & 1.15 & 0.250 & 0.879206 & 1.639433 \\
\hline $35-49$ & 1.606670 & 0.259586 & 2.93 & 0.003 & 1.170577 & 2.205227 \\
\hline $50+$ & 1.523480 & 0.249603 & 2.57 & 0.010 & 1.105041 & 2.100367 \\
\hline
\end{tabular}

Outcome 0 (think that the actual inflation rate is below 25 per cent) is the base outcome. The reference group is Asian males who are between the age of 25-34.

Source: BER

Similarly, it is attempted to determine what percentage of which gender group thinks that the perceived inflation rate will be higher than 25 per cent, as opposed to less than 25 per cent. It seems that gender did not significantly influence respondents' decisions on whether they perceived inflation to be above or below 25 per cent. There is therefore no significant difference between the inflation expectations of males and females.

The same structure is applied to establish what percentage of which age group thinks that the perceived inflation rate will be higher than 25 per cent, rather than less than 25 per cent. Similar to gender, it seems that age does not significantly influence respondents' decisions on whether they perceive inflation to be above or below 25 per cent. There is therefore no significant difference between the inflation expectations of different age groups.

Second, this analysis attempts to determine what percentage of which population group "did not know" what they perceived the inflation rate to be over those who thought that the perceived inflation rate was lower than 25 per cent. The output from the regression shows that the odds are 42,4 per cent (i.e. 100(1-0,576164)) lower for Whites than for Asians in this respect. Similarly, it is attempted to determine what percentage of which age group "did not know" what they perceived the inflation rate to be, as opposed to those who thought that the perceived inflation rate was lower than 25 per cent. The results suggests that the odds are 60,6 per cent higher for respondents in the age group 35-49 than for those in the age group 25-34 Moreover, the odds increased by 52,3 per cent for people older than 50 years, in comparison with those in the age group 25-34. When considering what percentage of which gender group "did not know" what they perceived the inflation rate to be, as opposed to those who thought that the actual inflation rate was lower than 25 per cent, no significant difference was seen between the responses by male and female respondents.

The relative risk ratios (RRR) analysed at the 90 per cent confidence interval on a null hypothesis $H_{0}$ : inflation credibility are the same for all respondents. At a 10 per cent significance level the critical $Z$ value will be equal to 1,645 , therefore "not rejecting" the $H_{0}$, if the calculated $Z$ lies between $-1,645$ and $+1,645$.

Table 2 displays the results of an inflation credibility multinomial logit regression model. The bold values represent those categories which fell outside the acceptance zone, as calculated by the above $Z$ score criteria. First, this analysis attempts to determine what percentage of which gender group did not accept the inflation rate as accurate, in comparison with those who did 
accept it as accurate. The output from the regression in Table 2 suggests that the odds in this respect are 29,0 per cent higher for females than for males. The results further suggest that the odds are 41,5 per cent higher for participants over 50 years to not accept inflation as accurate than for those between 25-34. No significant difference in inflation accuracy was noted between population groups.

\section{Table 2}

Output from the multinomial regression model for inflation credibility

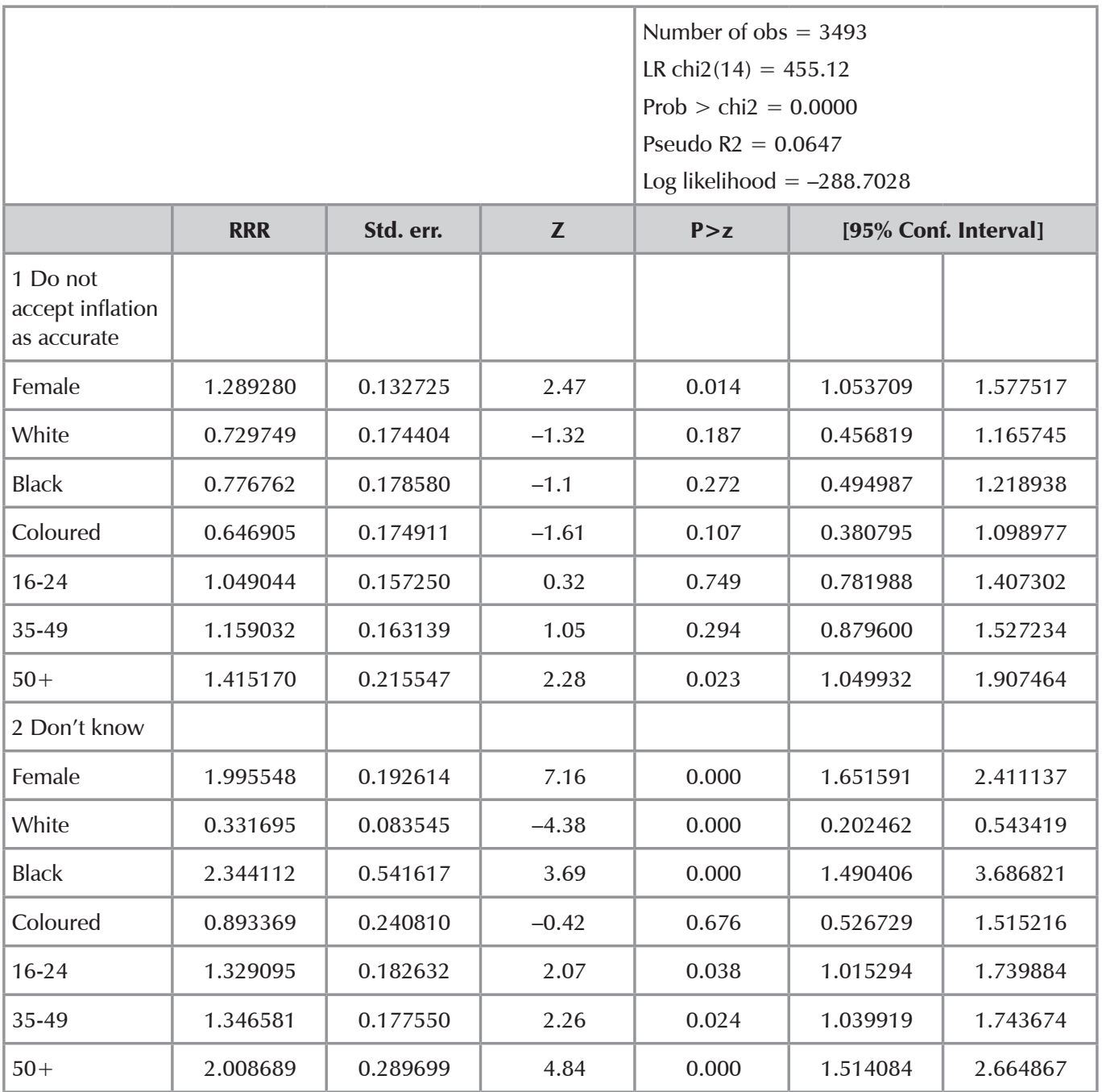

Outcome 0 (Accept inflation as accurate) is the base outcome. The reference group is Asian males who are between the age of 25-34.

Source: Markinor

Second, this analysis attempts to determine what percentage of which gender group "did not know" whether they accepted the inflation rate as accurate or not, compared to those who did accept it as accurate. The results show that the odds increase by 99 per cent for female participants, as compared to males in this regard. There is therefore a significant difference between female and male respondents who accept the inflation rate 
as accurate. Similarly, there is an attempt to determine what percentage of which population group "did not know" whether they accepted the inflation rate as accurate or not, compared to those who did accept it as accurate. The output shows that the odds decrease by 66,8 per cent for Whites to "not know", as opposed to Asians. On the other hand the odds are 134,4 per cent more for Blacks, than for Asians.

This analysis also considers what percentage of which age group "did not know" whether they accepted it the inflation rate as accurate or not, compared to those who did accept it as accurate. The results show that the odds increase by 32,9 per cent for participants between the ages of 16-24, compared to those between 25-34 years. Moreover, the odds increase in this respect for those between 35-49 and those older than 50 by 34,7 per cent and 100,9 per cent respectively, compared to those aged between 25-34.

Based on these null hypotheses, it transpires that subsamples increase the use of information within surveys of inflation credibility. This approach highlights considerable differences in perception between subsamples of respondents.

\section{8}

\section{Conclusions}

The first conclusion is that all countries targeting inflation consider inflation expectations, but that such expectations are measured in different ways, ranging from surveys to the use of interest rate differentials on different classes of assets. As no uniform approach is in use, the results can at best be compared only with the necessary circumspection.

Secondly, inflation credibility is considered in only three countries targeting inflation. Given reported problems with a lack of inflation credibility, this is a remarkable finding. The expectation was that such credibility would receive much broader attention in countries targeting inflation.

Thirdly, this paper shows the linking of inflation credibility and inflation expectations, particularly in the case of White respondents and of respondents of over 50 years of age. This result was expected and confirms the hypothesis in respect of these subsamples of respondents. White respondents were more likely to accept inflation as accurate and inflation to be less than 25 per cent. In both models, respondents of above 50 years of age were more likely to respond "don't know" in comparison with respondents between 25-34 years.

Fourthly, the most interesting finding is that male and female respondents show a possible disconnect between inflation expectations and inflation credibility. Whereas inflation credibility is considerably lower among female respondents than among males, these two groups report similar inflation expectations. In this instance the hypothesis is refuted. Lastly, this disconnect between female and male respondents cannot be explained by available data. Further research using similar models will be necessary once other inflation credibility surveys have been undertaken to assess this disconnect. This paper sets the benchmark for such future analysis.

\section{Endnotes}

1. The views and opinions expressed in this paper do not necessarily reflect the views and opinions of the SA Reserve Bank or any of the Universities. The authors wish to thank Mr Fanie Joubert of the Department of Economics at Unisa, as well as the editor and two anonymous referees for useful comments and suggestions to improve earlier drafts of this paper. The usual disclaimer applies.

2. It can be argued that these are individual responses, rather than collective household responses.

3. The International Monetary Fund identifies countries as inflation targeters once they have committed themselves to "... a unique numerical target in the form of a level or a range for annual inflation. A single target for inflation emphasises that price stabilisation is the primary focus of the strategy, and the numeric specification provides a guide to what the authorities intend as price stability ... (and accept inflation forecasting as) ... the de facto intermediate target of policy" (2005: 162). This definition is used to identify countries as inflation targeters.

4. Any cluster of countries identified as inflation targeters can be the subject of criticism inasmuch as it can be claimed that it is not a complete list. Examples of countries and/or central banks that are not included in this cluster, but that are 
sometimes referred to in literature as inflation targeters by sources other than the respective central banks, include:

- Albania, Ecuador and Kyrgyz Republic, which are identified as inflation targeters by Ravenna (2005: 35) but not by other sources, owing to the simultaneous use of M3 money supply targets in Albania (Bank of Albania, [S.a.]), dollarisation in Ecuador which “... results in a loss of flexibility in monetary policy ..." (Saville et al., 2005: 682), and a policy of foreign exchange market intervention in Kyrgyz Republic (National Bank of the Kyrgyz Republic, [S.a.]);

- Turkey, which is identified as an inflation targeter by the SA Reserve Bank (2008a: 47), but is not regarded as such by other sources owing to its additional special focus on exchange rate management (Central Bank of the Republic of Turkey, 2007: 8, 9);

- Costa Rica and Guatemala, which are regarded as inflation targeters by Turkey (Central Bank of the Republic of Turkey, 2008: 3), but not by other sources, owing to the policy of crawling exchange rate devaluation in Costa Rica (Korander, 2007: 27-30), and the focus on exchange rate and credit policies in Guatemala (Banco de Guatemala, 2007); and the European Central Bank (ECB), Federal Reserve in the United States of America (Fed) and the SNB. The ECB is excluded because it gives a special status to growth in the M3 money aggregate in the Euro area, while the Fed is excluded owing to the lack of a numerical specification for its price stability objective (International Monetary Fund, 2005: 162). Although the monetary policy framework of the SNB has many features of inflation targeting, it objects to its classification as an inflation targeter (Allen et al., 2006: 5).

5. It is beyond the scope of this paper to consider whether any inflation-targeting countries abandoned this policy model in view of recent international financial turmoil (see, for instance, Rossouw \& Padayachee, 2009, on this possibility).

6. The assessment by the Bank of Iceland (2003) is in the main a summary of the findings of Fracasso et al., 2003.

7. Owing to insufficient information, the Central Bank of Colombia was excluded from this assessment, while the Swiss National Bank (SNB) was included. Please see footnote 6 in respect of the SNB.
8. Independent inflation forecasts undertaken in South Africa by Reuters are reported in the biannual Monetary Policy Review of the SA Reserve Bank (see, for instance, SA Reserve Bank, 2008b: 32). As Reuters calls its survey a forecast, it is not considered in this paper, although it is reported as inflation expectations by the SA Reserve Bank.

9. These results are not reported in the bi-annual Monetary Policy Review of the SA Reserve Bank (SA Reserve Bank, 2008b), but are published biannually by the BER.

10. Omnibus research to contain the cost of surveys is an accepted research practice in many disciplines of study (see, for instance, Camponovo, 2006; or Lindenmann, 2001).

11. For the purpose of this paper, the category Blacks excludes Asians and Coloureds.

12. Struwig and Stead (2001) can be consulted on the use of pilot studies in preparation for broad surveys of populations.

13. The number of respondents were reduced to 3 493 after a 20-per-cent back-check to validate the results (Markinor, 2006).

14. The benchmark category is automatically selected by the software package.

\section{References}

\section{General sources}

ADDISON, E. 2008. Monetary policy and price stability in the West African Economic and Monetary Union (WAEMU) zone: constraints and challenges. 16-17 June. Dakar, Senegal.

ALLEN, M., BAUMGARTNER, U. \& RAJAN, R. 2006. Inflation targeting and the IMF. Washington: International Monetary Fund.

AMOAH, B. \& MUMUNI, Z. 2008. Choice of monetary policy regime in Ghana. Bank of Ghana Working Paper, WP/BOG - 2008/07. July.

BANCO DE GUATEMALA. 2007. Monetary, foreign exchange rate and credit policy: Evaluation to November 2007 and proposal for 2008, Resolution JM-211-2007. BANK FOR INTERNATIONAL SETTLEMENTS.

2008. Monetary policy decisions: Preparing the inputs and communicating the outcomes. BIS papers No. 37, Bank for International Settlements.

BANK OF ALBANIA. [S.a.]. Monetary policy

objectives. [Online] http://www. bankofalbania.org/

[Accessed on 27 August 2008].

BECHTOLD, S. \& LINZ, S. 2005. Enhancing the credibility of the consumer price index. [Online] http:// www.oecd.org/dataoecd/22/46/35281409.pdf [Accessed on 9 November 2005]. 
BLINDER, A.S., EHRMANN, M., FRATZSCHER, M., DE HAAN, J. \& JANSEN, D-J. 2008. Central bank communication and monetary policy: A survey of theory and evidence. European Central Bank Working Paper Series No. 898.

BLINDER, A.S. \& WYPLOSZ, C. 2005. Central bank talk: Committee structure and communication policy. Paper presented at Central bank communication, ASSA meetings, Philadelphia. 9 January.

BRACHINGER, H.W. 2005. Measuring perceived inflation: a prospect theory approach. $55^{\text {th }}$ session of International Statistical Institute, Voorburg, Netherlands in Sydney. 5-12 April.

BUREAU FOR ECONOMIC RESEARCH. 2006.

Survey of inflation expectations - results report: $4^{\text {th }}$ quarter of 2006. Stellenbosch: University of Stellenbosch. CAMPONOVO, G. 2006. Conceptual models for designing information systems supporting the strategic analysis of technology environments. Unpublished $\mathrm{PhD}$ thesis. Lausanne: University of Lausanne.

CARARE, A. \& STONE, M.R. 2003. Inflation targeting regimes. IMF Working Paper, WP/03/9, January.

\section{CENTRAL BANK OF THE REPUBLIC OF}

TURKEY. 2007. Monetary and exchange rate policy for 2008, 18 December

DÖHRING, B. \& MORDON, A. 2007. What drives inflation perceptions?: A dynamic panel data analysis. Directorate-General for Economic and Financial Affairs of the European Commission Economic Papers, No. 284. July.

DU PLESSIS, S.A. 2003. Much ado about nothing: a note on the modified inflation target. South African Journal of Economics, 71: 2. June.

2005. The democratic deficit and inflation targeting. South African Journal of Economics, 73: 1. EHRMANN, M. \& FRATZSCHER, M. 2005. How should central banks communicate? European Central Bank Working Paper Series, No. 557.

ESSOP, H. \& YU, D. 2008. The South African informal sector (1997-2006). Development Policy Research Unit Economic Working Paper 03/08. Stellenbosch: University of Stellenbosch. [Online] http://www.ekon.sun.ac.za/wpapers/2008/wp032008/ wp-03-2008.pdf. [Accessed on 31 August 2009]. FRACASSO, A., GENBERG, H. \& WYPLOSZ, C. 2003. How do central banks write? Geneva: ICMB. FORSELLS, M. \& KENNY, G. 2002. The rationality of consumers' inflation expectations: Survey-based for the Euro Area. European Central Bank Working Paper Series, Working Paper, No 163.

GONÇALVES, C.E.S. \& SALLES, J.M. 2005. Inflation targeting in emerging economies: What do the data say? Seminar at the University of Sao Paulo. 27 June.
[Online] http://www.econ.fea.usp.br/seminarios/2005 2/11_08_2005_carlos eduardo .pdf\#search $=\% 22 \% 22$ inflation $\% 20$ targeters $\% 22 \% 22$ [Accessed on various dates]. INTERNATIONAL MONETARY FUND (IMF). 2005. World Economic Outlook. September. ISSING, O. 2006. Einführung in die geldtheorie. 14., Auflage. Verlag Franz Vahlen: München. Translation assistance by Mr H.H. van Gass, SA Reserve Bank. INVESTEC. 2008. StatsSA at it again. Statement by Investec asset management. 15 July. JONUNG, L. 1981. Perceived and expected rates of inflation in Sweden. American Economic Review. 71: 5. KAHN G. A. \& PARISH, K. 1998. Conducting monetary policy with inflation targets. Economic Review. Federal Reserve Bank of Kansas City. Third quarter

KERSHOFF, G. 2000. Conducting inflation expectation surveys in South Africa. Publication of the Bureau for Economic Research: University of Stellenbosch. 24 October.

KERSHOFF, G.J., LAUBSCHER, P. \& SCHOOMBEE, A. 1999. Measuring inflation expectations - the international experience. Publication of the Bureau for Economic Research: University of Stellenbosch. December.

KORANDER, T. 2007. Peso problem and devaluation expectations: Evidence from Latin America.

Unpublished master's thesis. Lappeenranta University of Technology: Helsinki.

LANCASTER, T. 2004. An introduction to modern

Bayesian econometrics. Oxford, UK: Blackwell Publishing.

LEEPER, E. M. 2003. An "inflation reports" report. Economic Review 3. Swedish Riksbank.

LINDENMANN, W. K. 2001. Research does not have to put you in the poorhouse. [Online] people.ku.edu/ $\sim$ dguth/Lindenmann.pdf - Supplemental Result [Accessed on 7 March 2007].

MARKINOR. [S.a.]. Webpage. [Online] http://www. markinor.co.za/index.html [Accessed on various dates]. 2006. Project inflation credibility: Results

presentation. December.

MBOWENI, T.T. 2008. Governor's address. Address at the $88^{\text {th }}$ ordinary general meeting of shareholders of the SA Reserve Bank. 18 September.

MLATSHENI, C. \& LEIBBRANDT, M. 2001. The role of education and fertility in the participation and employment of African woman in South Africa. Development Policy Research Unit. University of Cape Town. DPRU working paper No.01/54. [Online] http://www.commerce.uct.ac.za/Research_Units/dpru/ WorkingPapers/PDF_Files/wp54.pdf [Accessed on 31 August 2009]. 
NATIONAL BANK OF THE KYRGYZ REPUBLIC. [S.a.]. Monetary policy instruments. [Online] http://www. nbkr.kg/web/interfeis.builder_frame?language =ENG. [Accessed on 27 August 2008]. NATIONAL GAMBLING BOARD. 2005. Socioeconomic impact of legalised gambling in South Africa. Pretoria: National Gambling Board.

PALMQVIST, S. \& STROMBERG, L. 2004.

Households' inflation opinions - a tale of two surveys.

Economic Review, 4. [Online] http://www.riksbank.com/ upload/Dokument_riksbank/Kat_publicerat/Artiklar_ PV/ER042.pd [Accessed on various dates]. PINDYCK, R.S. \& RUBINFELD, D. 1981.

Econonometric models and economic forecasts. New York: McGraw-Hill.

PORTUGAL, M. 2008. Navigating the financial storm: The financial market crisis and the global economic outlook - lessons and policy challenges. Remarks at the Annual Meeting of Institute for International Finance. 7 March.

RAVENNA, F. 2005. The European Monetary Union as a commitment device for new EU member states. European Central Bank Working Paper, No. 516. RESERVE BANK OF NEW ZEALAND. [S.a.]a. J5 Marketscope survey - expectations of inflation. [Online] http//.www.rbnz.govt.nz [Accessed on various dates]. RESERVE BANK OF NEW ZEALAND. [S.a.]b. J6 Survey of expectations - a survey of businesses. [Online] http//.www.rbnz.govt.nz [Accessed on 6 August 2008]. ROSSOUW, J. 2008. Inflation in South Africa: 1921 to 2006. History, measurement and credibility. Unpublished PhD thesis. University of KwaZulu-Natal: Durban. ROSSOUW, J. \& JOUBERT, F. 2005. Supporting an inflation-targeting policy with the measurement of inflation credibility. South African Journal of

Economics, 73: 2.

ROSSOUW, J. \& PADAYACHEE, V. 2007. A study on inflation credibility among students at the University of Pretoria. South African Journal of Economic and Management Sciences, 10: 1.
2009. Measuring inflation credibility: Results of a first representative South African sample. $S A$ Journal of Economics, 77: 2.

SA RESERVE BANK. 2008a. Annual Report. SAVILLE, A., BADER, M. \& SPINDLER, Z. 2005. Alternative monetary systems and the quest for stability: can a free banking system deliver in South Africa? South African Journal of Economics, 73: 4. STRUWIG, F.W. \& STEAD, G.B. 2001. Planning, designing and reporting research. Cape Town: Pearson Education South Africa.

SVERIGES RIKSBANK. [S.a.]. Inflation expectations. [Online] http://www.riksbank. com/templates/Page. aspx?id=10551 [Accessed on 1 July 2005]. VAN HEERDEN, C. \& STYGER, P. 2009. A note on Rossouw and Padayachee: measuring inflation credibility: results of a first representative South African sample. Research note of the School of Economics. Potchefstroom: North-West University. VEGA, M. \& WINKELRIED, D. 2005. Inflation targeting and inflation behavior: A successful story? International Journal of Central Banking, 1: 3. VIÑALS, J. 2007. Panel remarks. NBER Conference on International dimensions of monetary policy, S'Agaró, Spain. June.

\section{Monetary policy reports}

Monetary policy reports of central banks of inflationtargeting countries highlighted in Table A1.

BANCO CENTRAL DE CHILE. 2008. Monetary policy report, January.

BANK OF ICELAND. 2003. Monetary bulletin, 5: 3. August.

SA RESERVE BANK. 2008b. Monetary policy review, May.

SVERIGES RIKSBANK. 2008. Monetary policy report, 2/2008. 


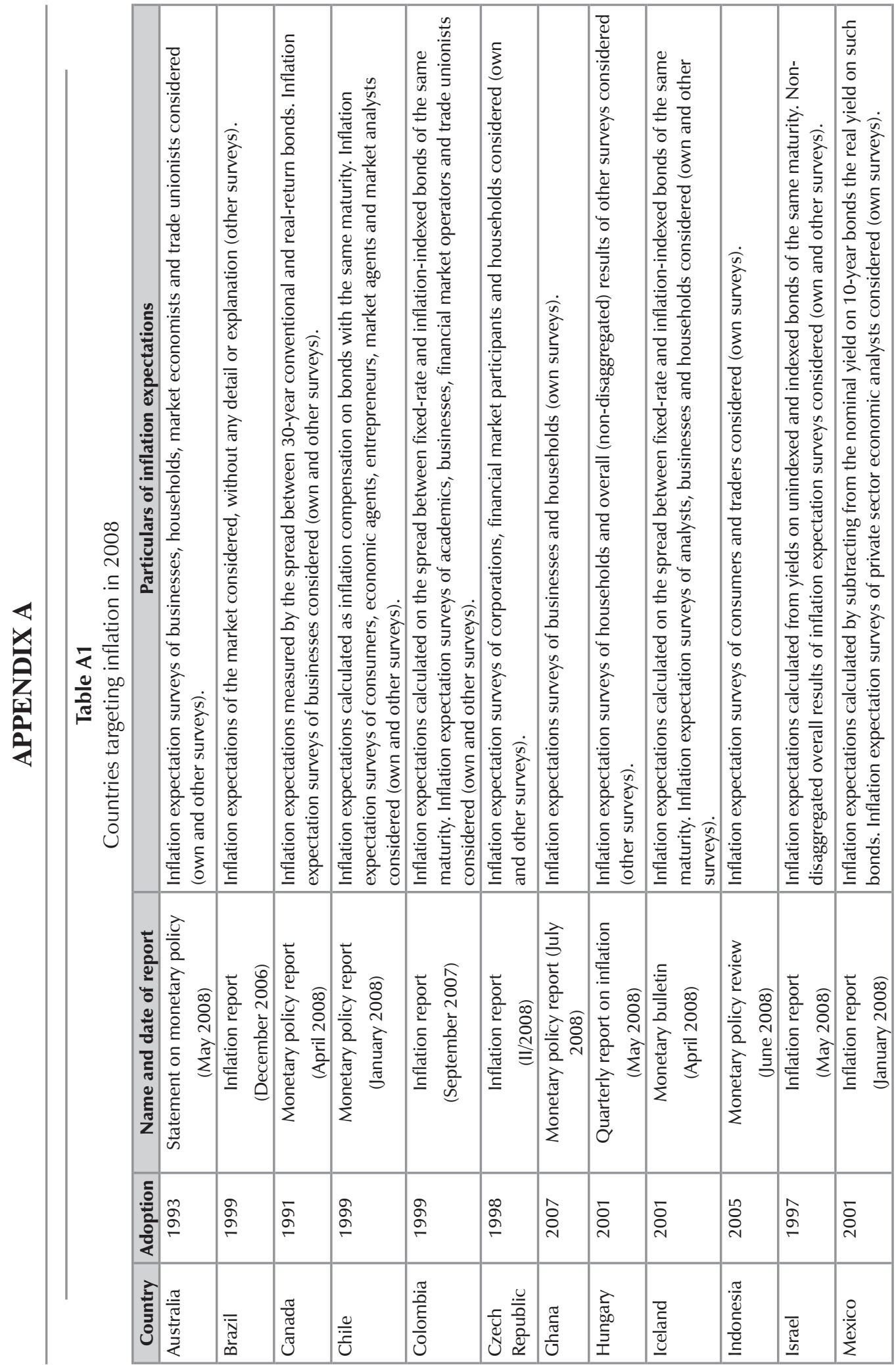




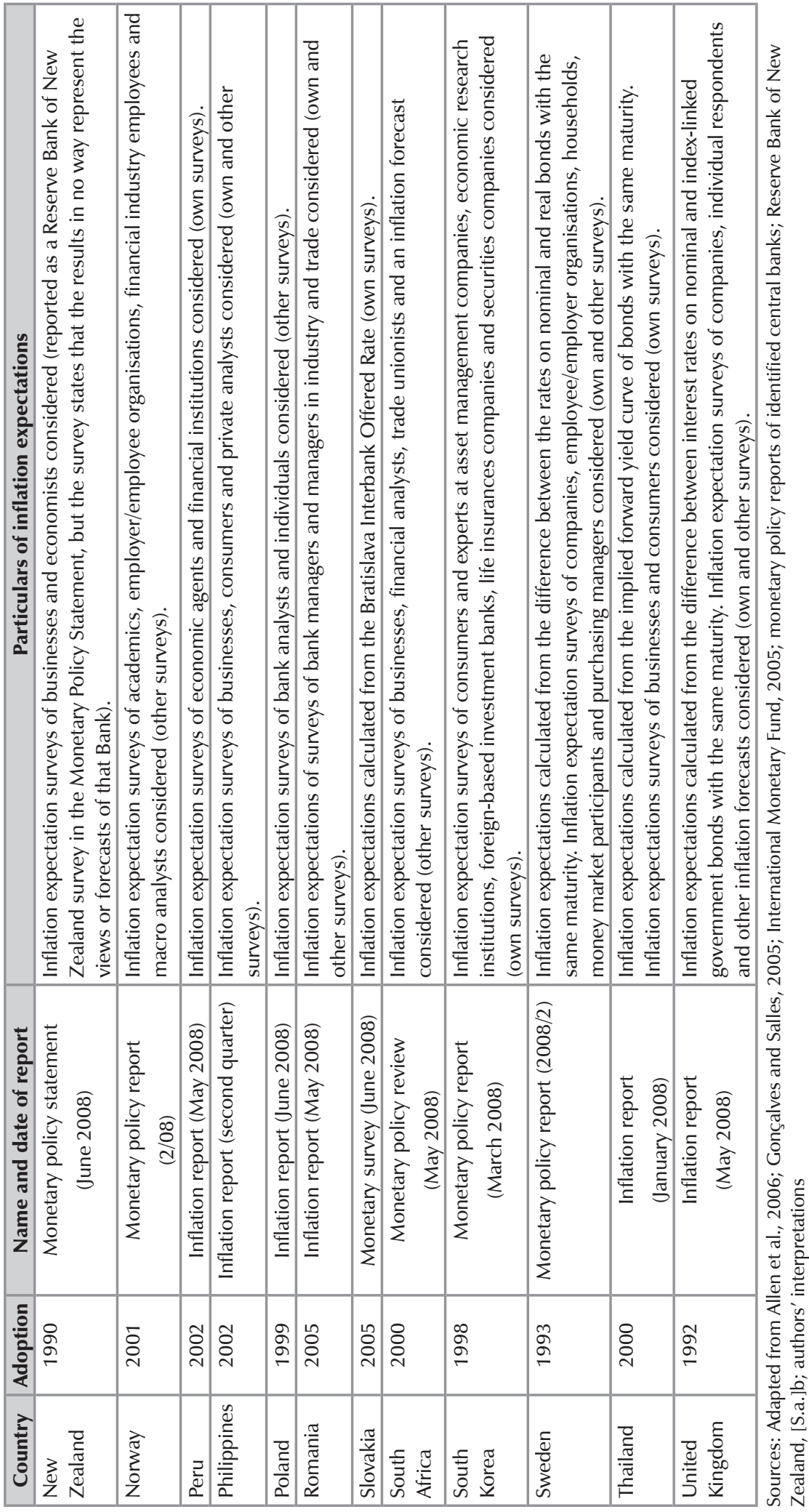




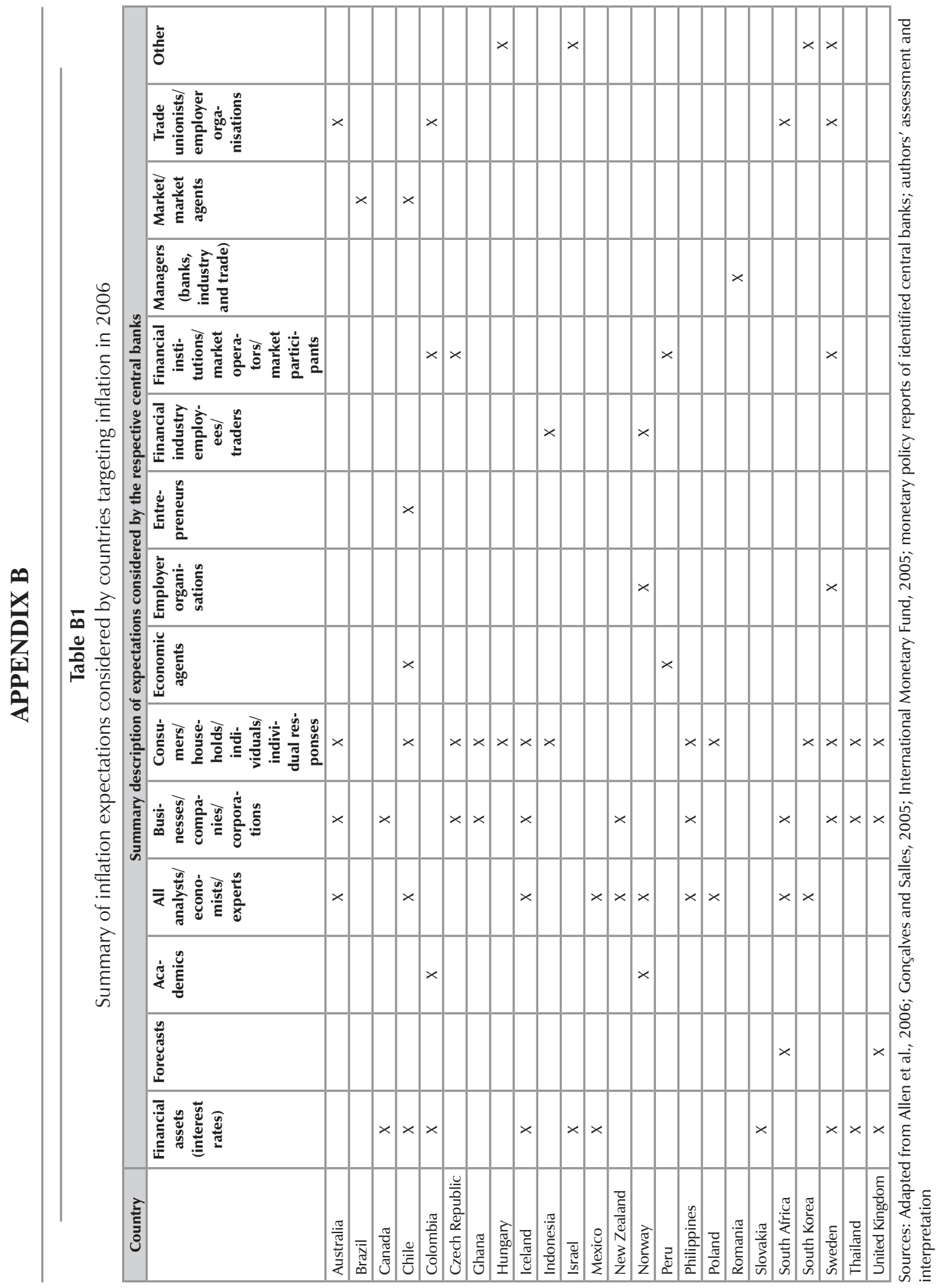




\section{APPENDIX C}

\section{Table C1}

Average of responses about inflation expectations according to age, gender, population group and the total, $4^{\text {th }}$ quarter 2006

\begin{tabular}{|c|c|c|c|}
\hline & $\begin{array}{l}\text { Average expected rate } \\
\text { of inflation }\end{array}$ & $\begin{array}{c}\%>25 \% \\
\text { (\% respondents) }\end{array}$ & $\begin{array}{c}\text { \% don't know } \\
\text { (\% respondents) }\end{array}$ \\
\hline \multicolumn{4}{|l|}{ Age } \\
\hline $16-24$ & 4,7 & 5,7 & 17,8 \\
\hline $25-34$ & 4,7 & 5,7 & 16,9 \\
\hline $35-49$ & 5,0 & 4,9 & 23,0 \\
\hline $50+$ & 5,6 & 4,7 & 22,8 \\
\hline \multicolumn{4}{|l|}{ Gender } \\
\hline Female & 5,0 & 5,1 & 21,8 \\
\hline Male & 5,0 & 5,4 & 18,9 \\
\hline \multicolumn{4}{|c|}{ Population group } \\
\hline Asians & 5,4 & 6,9 & 18,4 \\
\hline Blacks & 4,8 & 6,3 & 22,8 \\
\hline Coloured & 4,8 & 4,9 & 20,4 \\
\hline Whites & 5,5 & 1,8 & 12,9 \\
\hline Total & 5,0 & 5,2 & 20,3 \\
\hline
\end{tabular}

Source: Bureau for Economic Research, 2006: 16 


\section{APPENDIX D}

\section{Table D1}

Responses about inflation credibility according to age, gender, population group and the total, adjusted for purposes of comparability to the inflation expectations survey results reported in Appendix C above, $4^{\text {th }}$ quarter 2006

\begin{tabular}{|c|c|c|c|c|c|c|}
\hline \multirow[b]{2}{*}{ Age } & \multicolumn{2}{|c|}{$\begin{array}{l}\text { Number and \% accepting } \\
\text { inflation as accurate }\end{array}$} & \multicolumn{2}{|c|}{$\begin{array}{c}\text { Number and \% not } \\
\text { accepting inflation as } \\
\text { accurate }\end{array}$} & \multicolumn{2}{|c|}{ Number and \% don't knou } \\
\hline & $\mathbf{n}$ & $\%$ & $\mathbf{n}$ & $\%$ & $\mathbf{n}$ & $\%$ \\
\hline $16-24$ & 151 & 18,3 & 211 & 25,5 & 465 & 56,2 \\
\hline $25-34$ & 158 & 20,7 & 215 & 28,2 & 390 & 51,1 \\
\hline $35-49$ & 196 & 19,0 & 306 & 29,7 & 527 & 51,2 \\
\hline $50+$ & 140 & 16,0 & 267 & 30,5 & 467 & 53,4 \\
\hline \multicolumn{7}{|l|}{ Gender } \\
\hline Female & 254 & 14,6 & 457 & 26,2 & 1034 & 59,3 \\
\hline Male & 391 & 22,4 & 542 & 31,0 & 815 & 46,6 \\
\hline \multicolumn{7}{|c|}{ Population group } \\
\hline Asians & 31 & 19,6 & 65 & 41,1 & 62 & 32,9 \\
\hline Blacks & 364 & 14,8 & 559 & 22,7 & 1540 & 62,5 \\
\hline Coloured & 70 & 24,6 & 93 & 32,6 & 122 & 42,8 \\
\hline Whites & 180 & 30,7 & 282 & 48,0 & 125 & 21,3 \\
\hline Total & 645 & 18,5 & 999 & 28,6 & 1849 & 52,9 \\
\hline
\end{tabular}

